\title{
Usability of an E-Commerce Website Using Information Mining and Artificial Intelligence
}

\author{
Pankaj Gupta ${ }^{1}$, Bharat Bhushan Sagar ${ }^{2}$ \\ Computer Science \& Engineering, Birla Institute f Technology,Mesra:Ranchi, India \\ ${ }^{1}$ pgupta@bitmesra.ac.in, ${ }^{2}$ drbbsagar@gmail.com
}

\begin{abstract}
Everyday a number of people are launching new websites of which many are e-Commerce websites. E-Commerce website means business and to have business they have to be useful to the customer. So, it is very important for the e-Commerce site to get the trust of the customer. Or in other words the trustworthiness of an e-Commerce site is very important to have business. Usability can be increased by enhancing trust. How much a customer trusts a website becomes a fundamental question which beckons for an answer. More a customer trusts a website, more he will be using the website. This article includes a study on website usability, trust evaluation and how to improve trust to improve the usability of a website. Here we find the different factors that affect the quality of an ecommerce site. Based on these factors the trustworthiness of an e-commerce site is calculated using Matlab.
\end{abstract}

Index Terms-E-commerce, Website, Information Mining, Usability, Trust, Artificial Intelligence, Matlab.

\section{INTRODUCTION}

$\mathrm{T}$ HE NATURE of a site can be surveyed in various ways. To date, investigations of sites have concentrated on site ease of use. So, usability is a very important concept. Ease of use is a subjective rating of how simple a site is to utilize, and on account of web based business, how likely it is that a potential client will be changed over to a genuine one. Usability can be increased by enhancing trust [2]. An estimation of ease of use comprises of a few unique variables, however comes down to how well a site gives its guests what they are truly searching for. So, usability of a site simply means whether a customer is finding a site to be useful or not.

1. Factors That Decides Website Usability [3]:

a. How individuals visit destinations?

b. Why and when they take off?

2. Simplicity and highlight decision

3. Flow

4. Feedback

5. Navigation and data engineering

a. Category and connection names

b. Link plan c. Click-capacity and saw affordance

d. Persistent route

e. Pop-ups

f. Opening new program windows

6. Page format

7. Enhancing believability and trust

8. Loyalty: Enticing clients to return

a. Registration

b. Value-included highlights for rehash clients

9. Information rummaging
a. User consideration
b. Scrolling
c. Information fragrance

10. Search
a. Query strings
b. How individuals utilize internet searcher comes about pages (SERP)
c. Improving site-particular pursuit

11. Content ease of use
a. How clients read on the web?
b. Writing for the Web
c. Low-education clients
d. Presentation of content: clarity and coherence

This article includes a study on website usability, trust evaluation and how to improve trust to improve the usability of a website [1].

Acceptance Leads To Usability: One approach to see whether a web based business webpage will be acknowledged by a client is to apply Technology Acceptance Model (TAM). This model expresses that the accomplishment of a framework can be controlled by client acknowledgment of the framework measured by two factors: the Perceived Usefulness (PU) of the framework and Perceived usability 


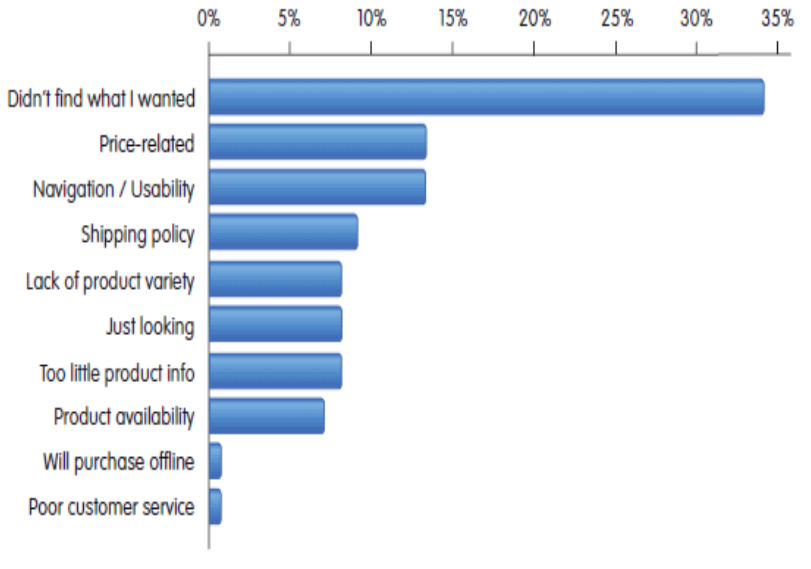

Figure 1: Why a Potential Customer may not find a Web-Site to be Useful.

(PEOU) of the framework. As indicated by this model, a client's recognition about a frameworks value and usability brings about a goal to utilize [6].

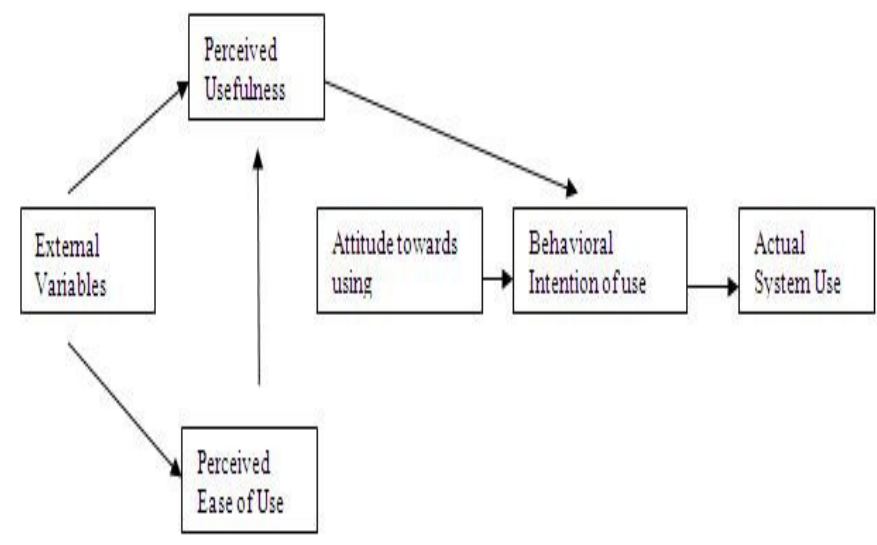

Figure 2: Acceptance Model

The TAM has been tried in numerous experimental examinations and observed to be very legitimate and dependable and is generally referenced. So, trust is a factor which determines whether a customer will like an e-commerce site or not. More a person trusts a site, more he will visit and use that particular site. If we can increase the trust of a person the usability of the site increases.

For the purpose of my analysis I have chosen one variable, viz., TRUST.

Trust: Trust is a complicated subject identified with confidence in trustworthiness, trustfulness, skill, and unwavering quality of an element. In McKnight et al's. "The Meanings of Trust", the most substantial parts of trust will be trust conduct and confide in aim. With regards to web based business, trust is generally determined as far as a brief connection between a buyer and a merchant or item. In the present online business condition, the administration of confide in requirements to deal with many factors over numerous sites or spaces. Beth et al. classify the between area trust connections into two classes: coordinate trust and prescribed trust. In view of the desire for an element having the capacity to complete an undertaking, the framework can ascertain the likelihood of whether the element will finish the assignment in light of positive and negative involvement, measure the reliability utilizing this likelihood, and make a recipe for computing a number estimation of the dependability with an arrangement of induction and mix rules. However, this instrument rearranges genuine by displaying reliability construct just in light of likelihood, and compares the subjectivity and vulnerability to the haphazardness. In the meantime, it utilizes the mean estimation of numerous wellsprings of dependability as the pointer of the total trust and last trust esteem number, which discards conceivable weights on each put stock in source [9-11].

Fuzziness in Trust: The trust connections in multi-space web based business applications are difficult to evaluate because of included vulnerability. In the event that a trust relationship depends upon a subjective judgment in view of circuitous data, it will be extremely questionable and any operations identified with that trust relationship may cause sudden outcomes. Fluffy rationale is an appropriate approach to speak to vulnerabilities, particularly when they should be taken care of quantitatively. Two preferences of utilizing fluffy rationale to evaluate vulnerability in trust administration are: (1) Fuzzy induction is fit for evaluating loose information or vulnerability in measuring diverse levels of trust. (2) Different participation capacities and surmising tenets could be created for various put stock seeing someone, without changing the fluffy induction motors and implementation instruments. L. Zadeh first presented fluffy rationale in the advancement of the hypothesis of fluffy sets. The hypothesis of fluffy rationale broadens the metaphysics of scientific research to a composite that use quality and amount and contains certain fluffiness. We attempt to unravel the issues related with vulnerability in trust administration utilizing fluffy rationale [4], [7] [14].

How To Measure Trust: Simple variables like age, gender and income can each be measured by a single question. Complex phenomena, such as the degree of trust an individual has in an organization, cannot be measured through one question. Such constructs should be probed through a number of different questions to ensure that the researcher ends up with a meaningful response. Asking donors whether they trust an organization through simple yes / no question is meaningless. What does it mean to trust a nonprofit organization and is not it in any case a matter of degree. The fig. includes a group of questions that might be used to address this issue more effectively. If one measure of trust is required, taking the answers to these questions would be an appropriate [7], [18].

\begin{tabular}{lllllllllll} 
Sample Questions for & \multicolumn{1}{c}{ Low-degree Trust } & \multicolumn{4}{c}{ High-degree Trust } \\
measuring Trust & 1 & 2 & 3 & 4 & 5 & 6 & 7 & 8 & 9 & 10
\end{tabular}


The test of building a trust display is the means by which to viably assess trust. Two vital inquiries to be addressed are what elements to survey for confide in assessment and how to utilize these components in assessment. On the Internet, clients ordinarily see higher hazard contrasted with a regular shopping condition, because of separation, virtual character, and absence of control. In this manner trust is the preparatory condition to purchasers' web based business interest.

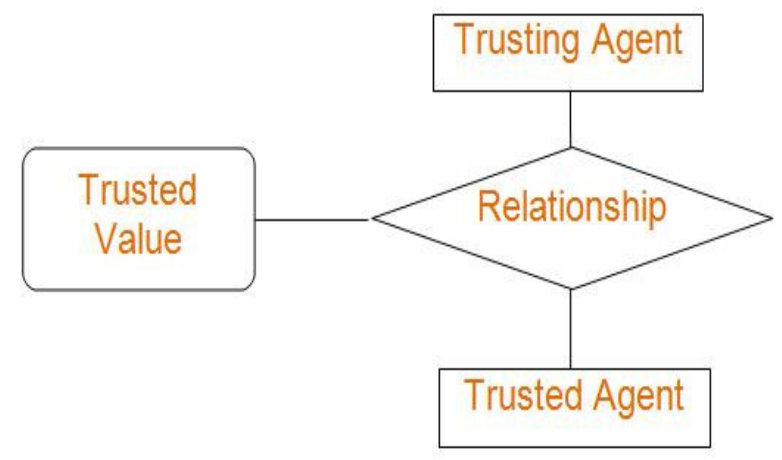

Figure 3: Trust Model

\section{Related Work}

Ease of use is a subjective rating of the fact that it is so natural to utilize a site, and on account of web based business, how likely it is that a potential client will be changed over to a genuine one. An estimation of ease of use comprises of a few distinct components, yet comes down to how well a site gives its guests what they are truly searching for. So, usability of a site simply means whether a customer is finding a site to be useful or not.

\section{Methodlogy of My Work}

I have used a survey analysis to obtain feed back of an ecommerce site. Based on the feedback results I have defined the membership functions of the factors. The results have been taken as input to the Matlab file and the output defined trustworthiness of the website [19].

\section{Work Flow:}

When we apply TAM to a particular site we can as well find out whether the user will accept that site or not. Various factors define a site and any site can be well described by the following factors (the list can be further expanded) [13].

Accuracy, availability, being-up-to-date, credibility, usefulness, durability, reliability, security.

According to TAM some of these factors will come under Perceived Ease of Use (PEU) and some will come under Perceived Usefulness [21].
Summary of Models of Trust in E-Commerce:

\begin{tabular}{|c|c|}
\hline Model Of Trust & Trust Attributes \\
\hline $\begin{array}{l}\text { Trust model for Online } \\
\text { Exchange [1] }\end{array}$ & $\begin{array}{l}\text { Precision, accessibility, being-progressive, } \\
\text { culmination, being unprejudiced, validity, } \\
\text { excitement, convenience, strength, } \\
\text { dependability, band value, temporariness, } \\
\text { quality, assortment, customization, } \\
\text { intensity and accessibility, } \\
\text { straightforwardness, estimating and } \\
\text { installment choice, monetary arranging, } \\
\text { deals related administration (discount } \\
\text { approach, after-deals and so on), } \\
\text { advancements , Delivery satisfaction, } \\
\text { Quality of media transmission, interface } \\
\text { plan and substance, security, reversibility, } \\
\text { computerized declaration, open key- } \\
\text { cryptography, genuineness, uprightness, } \\
\text { secrecy, notoriety, accreditation, } \\
\text { verification, endorsements, client group, } \\
\text { lawful necessities and specialists, } \\
\text { encounter, nature, hazard evaluation, } \\
\text { protection, fulfillment and subjective } \\
\text { appraisal, of reliability. }\end{array}$ \\
\hline $\begin{array}{l}\text { Towards Establishing } \\
\text { Customer supplier } \\
\text { Trust }[18]\end{array}$ & $\begin{array}{l}\text { Personality of the business site, offers of } \\
\text { free items or administrations, steady in } \\
\text { business, criticism, get to, route, basic buy. }\end{array}$ \\
\hline $\begin{array}{l}\text { Model of Trust for e- } \\
\text { Commerce System } \\
\text { Design [20] }\end{array}$ & $\begin{array}{l}\text { Business mark name, trusted outsider, } \\
\text { visual computerization, format, simple to } \\
\text { utilize, framework's unwavering quality, } \\
\text { characterization plans, phrasing, data about } \\
\text { item and administrations, security, } \\
\text { protection, following exchange and post- } \\
\text { buy administrations. }\end{array}$ \\
\hline $\begin{array}{l}\text { Internet Consumer } \\
\text { Trust Model [15] }\end{array}$ & $\begin{array}{l}\text { Understood, awful/great notoriety, } \\
\text { business measure, greatest/littlest player in } \\
\text { the market, individual mindful, store's } \\
\text { conduct and administrations. }\end{array}$ \\
\hline
\end{tabular}

\begin{tabular}{|l|l|}
\hline Groups & \multicolumn{1}{|c|}{ Factors } \\
\hline PU & $\begin{array}{l}\text { Accuracy, Being-up-to-date, Usefulness, } \\
\text { Security, Credibility }\end{array}$ \\
\hline PEU & Availability, Durability, Reliability \\
\hline
\end{tabular}

With respect to a site what these factors mean [12]

\begin{tabular}{|l|l|}
\hline Factors & What it means with respect to a site \\
\hline Accuracy & $\begin{array}{l}\text { How accurately and effectively the site is designed } \\
\text { so that it can process web orders and provide the } \\
\text { highest possible level of customer service. }\end{array}$ \\
\hline Availability & $\begin{array}{l}\text { High availability means an user do not even have to } \\
\text { worry about the site being going down. }\end{array}$ \\
\hline $\begin{array}{l}\text { Being-up-to- } \\
\text { date }\end{array}$ & $\begin{array}{l}\text { The site should always stay up to date with the latest } \\
\text { happenings and development. }\end{array}$ \\
\hline Usefulness & $\begin{array}{l}\text { How the information provided by the site is useful to } \\
\text { a user. }\end{array}$ \\
\hline Durability & $\begin{array}{l}\text { The site should able tp perform or compete over a } \\
\text { long period as by avoiding and overcoming damage. }\end{array}$ \\
\hline
\end{tabular}




\begin{tabular}{|l|l|}
\hline Reliability & $\begin{array}{l}\text { A site is said to be reliable if it guarantees its proper } \\
\text { service even at peak season/load. }\end{array}$ \\
\hline Security & $\begin{array}{l}\text { How secure a person feels while using sensible } \\
\text { information like credit card details and bank details } \\
\text { etc. }\end{array}$ \\
\hline Credibility & $\begin{array}{l}\text { How a customer feels over the long run after } \\
\text { repeated use of the website. }\end{array}$ \\
\hline
\end{tabular}

How questioner is develop:

The questioner is developed with the purpose of evaluating a website on the basis of factors as above on a scale 1 to 5 (A Linker scale is a scale commonly involved in research that employs questioners) 1 meaning strongly disagree and 5 means highly agree and intermediate numbers 2 to 4 expressing a range between these two extremities.

The design of the questioner is consistent with the quality norms of the website as well as the representative population who are expected to evaluate/use the particular website [16].

Based on the above factors a questionnaire is prepared which serves as a visitor's feed-back form.
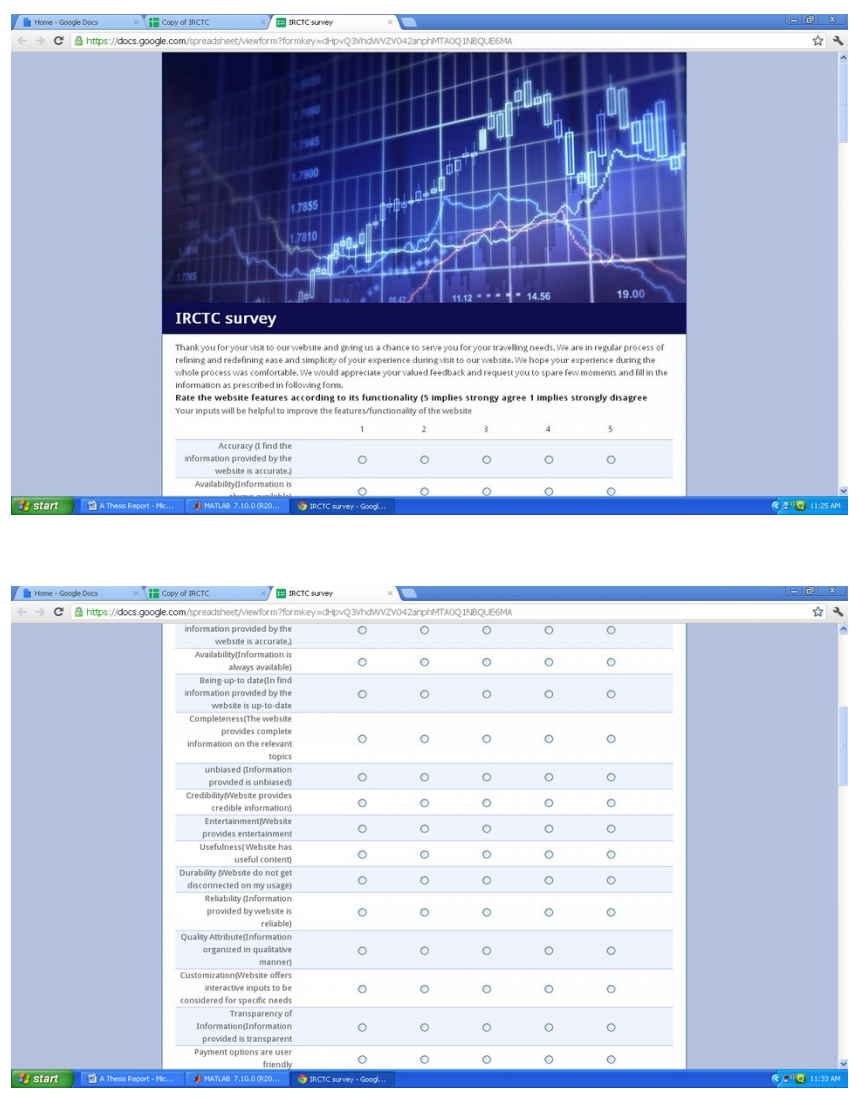

Figure 4: Feed Back Form

Fuzzification:_The factors which are being used to evaluate the website are highly subjective in nature, the result do not lead to a crisp evaluation but rather fuzzy in nature [17]. For particular factor say availability what we get from the screen is $1,2,3,4,5$ depending upon on which circle the visitor has put a tick mark. Next step is Fuzzification of the input.

\begin{tabular}{|l|l|}
\hline CRISP VALUE & FUZZY VALUE \\
\hline 5, Strongly Agree & Very high \\
\hline 4 & High \\
\hline 3 & Average \\
\hline 2 & Fair \\
\hline 1 Strongly Disagree, & Low \\
\hline
\end{tabular}

Here we will use Fuzzy Logic Tool Box of Matlab to represent the data which we have collected. Since the data is fuzzy in nature and Matlab is a very powerful technical language for mathematical reasoning.

Matlab Coding:

data $=$

\begin{tabular}{|c|c|c|c|c|}
\hline 3 & 5 & 3 & 3 & 4 \\
\hline 4 & 4 & 3 & 4 & 5 \\
\hline 2 & 3 & 3 & 3 & 4 \\
\hline 5 & 4 & 4 & 4 & 2 \\
\hline 3 & 5 & 4 & 5 & 5 \\
\hline 5 & 3 & 4 & 4 & 4 \\
\hline 4 & 4 & 5 & 3 & 4 \\
\hline 2 & 3 & 4 & 5 & 5 \\
\hline 3 & 3 & 4 & 3 & 3 \\
\hline 3 & 4 & 5 & 5 & 4 \\
\hline
\end{tabular}

numMFs $=\left[\begin{array}{lllll}5 & 5 & 5 & 5 & 5\end{array}\right]$;

mf Type = char('trimf,'trimf','trimf,'trimf','trimf');

fismat $=$ genfis $1($ data,numMFs,mfType $)$;

$[\mathrm{x}, \mathrm{mf}]=\operatorname{plotmf}($ fismat, 'input', 1$)$;

subplot(3,2,1), plot(x,mf);

xlabel('accuracy ');

$[\mathrm{x}, \mathrm{mf}]=$ plotmf(fismat,'input',2);

subplot(3,2,2), plot(x,mf);

xlabel('avalibility');

$[\mathrm{x}, \mathrm{mf}]=$ plotmf(fismat,'input',3);

subplot(3,2,3), plot(x,mf);

xlabel('credibility ');

$[\mathrm{x}, \mathrm{mf}]=$ plotmf(fismat,'input',4);

subplot $(3,2,4)$, plot(x,mf);

xlabel('reliability ');

$[\mathrm{x}, \mathrm{mf}]=$ plotmf(fismat,'input',5);

subplot(3,2,5), plot(x,mf);

xlabel('usefulness '); 


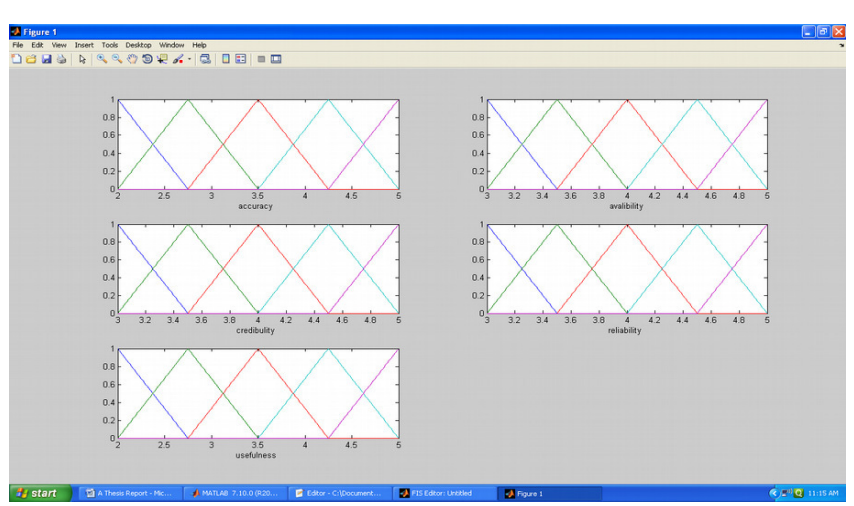

Figure 5: Fuzification

\section{Generation Input Membership Function:}

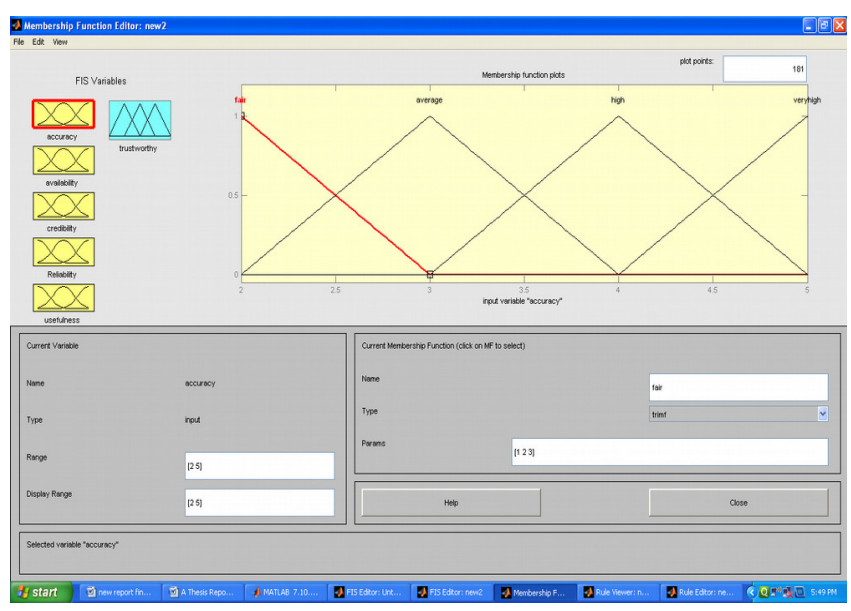

Figure 6: Membership Function for Input Variable 'Accuracy'

Similarly we will generate the membership function fr other variables and the output we get is shown in figure 7.

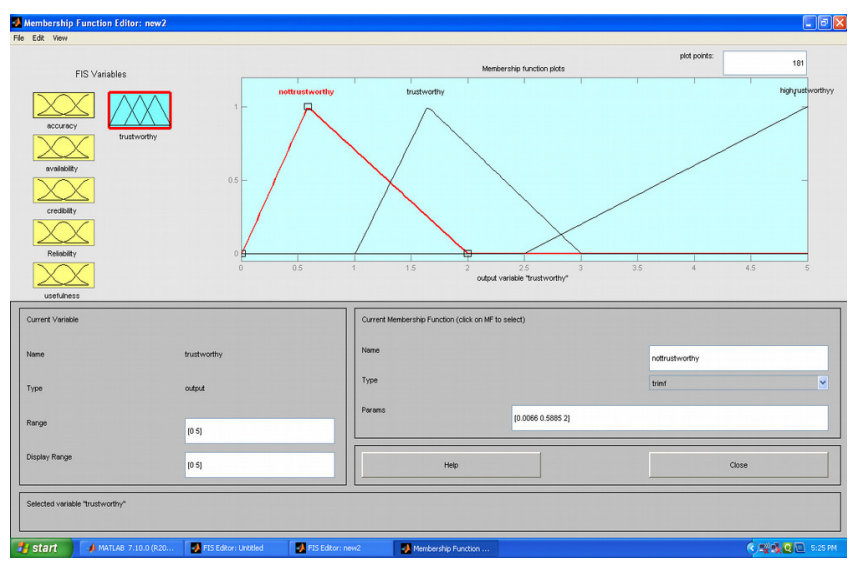

Figure 7: Output

The rules are formed in the following way:

\section{RULE:}

1. If accuracy is very-high and availability is very-high and credibility is very-high and reliability is very-high and use fullness is very high then highly trustworthy.

RESULT:

\begin{tabular}{|l|l|l|l|l|l|}
\hline $\begin{array}{l}\text { Accur } \\
\text { acy }\end{array}$ & $\begin{array}{l}\text { Availabi } \\
\text { lity }\end{array}$ & $\begin{array}{l}\text { Credibi } \\
\text { lity }\end{array}$ & $\begin{array}{l}\text { Reliabi } \\
\text { lity }\end{array}$ & $\begin{array}{l}\text { Usefuln } \\
\text { ess }\end{array}$ & $\begin{array}{l}\text { Trust } \\
\text { worthi } \\
\text { ness }\end{array}$ \\
\hline 2.5 & 2.5 & 2.5 & 2.5 & 2.5 & 2.5 \\
\hline 4.0 & 4.0 & 4.0 & 4 & 4 & 2.5 \\
\hline 4.92 & 4.85 & 4.92 & 4.92 & 4.92 & 4.18 \\
\hline
\end{tabular}

\section{RULE}

1. If accuracy is very-high and availability is very-high and credibility is very-high and reliability is very-high and usefulness is very high then highly trustworthy.

2. If accuracy is high and availability is high and credibility is high and reliability is high and use fullness is high then trustworthy.

3. If accuracy is average and availability is average and credibility is average and reliability is average and usefulness is average then not trustworthy.

\section{RESULT}

\begin{tabular}{|l|l|l|l|l|l||}
\hline $\begin{array}{l}\text { Accur } \\
\text { acy }\end{array}$ & $\begin{array}{l}\text { Availab } \\
\text { ility }\end{array}$ & $\begin{array}{l}\text { Credib } \\
\text { ility }\end{array}$ & $\begin{array}{l}\text { Reliabi } \\
\text { lity }\end{array}$ & $\begin{array}{l}\text { Usefuln } \\
\text { ess }\end{array}$ & $\begin{array}{l}\text { Trustwort } \\
\text { hiness }\end{array}$ \\
\hline 2.5 & 2.5 & 2.5 & 2.5 & 2.5 & .911 \\
\hline 4.0 & 4.0 & 4.0 & 4 & 4 & 1.89 \\
\hline 4.92 & 4.85 & 4.92 & 4.92 & 4.92 & 3.96 \\
\hline \multicolumn{7}{|l|}{} \\
\hline
\end{tabular}

RULE

1. If accuracy is very-high and availability is very-high and credibility is very-high and reliability is very-high and usefulness is very high then highly trustworthy.

2. If accuracy is high and availability is high and credibility is high and reliability is high and use fullness is high then trustworthy.

3. If accuracy is average and availability is average and credibility is average and reliability is average and usefulness is average then not trustworthy.

4. If accuracy is fair or availability is average or credibility is average or reliability is average or usefulness is average then not trustworthy.

\section{RESULT}

\begin{tabular}{|l|l|l|l|l|l|}
\hline $\begin{array}{l}\text { Accu } \\
\text { racy }\end{array}$ & $\begin{array}{l}\text { Availa } \\
\text { bility }\end{array}$ & $\begin{array}{l}\text { Credi } \\
\text { bility }\end{array}$ & $\begin{array}{l}\text { Relia } \\
\text { bility }\end{array}$ & $\begin{array}{l}\text { Usefu } \\
\text { lness }\end{array}$ & $\begin{array}{l}\text { Trustwort } \\
\text { hiness }\end{array}$ \\
\hline 2.5 & 2.5 & 2.5 & 2.5 & 2.5 & .865 \\
\hline 4.0 & 4.0 & 4.0 & 4 & 4 & 1.37 \\
\hline 4.92 & 4.85 & 4.92 & 4.92 & 4.92 & 3.96 \\
\hline
\end{tabular}




\section{CONCLUSION}

In this paper I have found out a method to find the trustworthiness and thus the usability of an e-commerce website. I have emphasized on the fact that the usability of an e-commerce site can be measured by measuring the trustworthiness of that site. To measure the trustworthiness of an ecommerce site I first made a survey of that particular site. The survey included various factors which described the site properly. Based on this survey I have made various rules by using fuzzy toolbox of Matlab. These rules helped me to calculate the trustworthiness of that particular e-commerce site. I also found out that trustworthiness of a web-site can be improved by improving the various factors which describe the site. This method can be used first to measure the trustworthiness and then to take effective periodic steps to maintain as well as increase the trustworthiness and thus usability of any e-commerce site.

Limitation: The limitation of the present work is that it is based on a sample data of a particular site only. It should include different sites because user of a particular site can be biased about the site. Web is dynamic in nature and more and more user using it. So, the parameter should be updated regularly.

Future Scope: In future we can design a rule based expert system which will provide expert-level solution to find the trustworthiness of an e-commerce site. The system will be flexible enough to accommodate future knowledge.

\section{REFERENCES}

[1] M A Islam, F Ahmed, Y Borodin, J Mahmud and I. V. Ramakrishnan, "Improving Accessibility of Transaction-centric Web Objects", SIAM International Conference on Data Mining (SDM), 2010.

[2] M Ahmed, J Kaysar and N Rahman, "Design Approaches to Enhance Usability for E-Commerce Sites", International Journal of Computer Science Issues, Vol. 8, Issue 6, No 1, 2011.

[3] http://www.networksolutions.com/education/what-is-ecommerce/

[4] Z Wu and H Wu, "An Agent based Fuzzy Recommendation system using shoppers Prefences for E-commerce Applications”, International
Journal Uncertainty Fuzzy Knowledge Based System, Vol. 18, pp. 471, 2010.

[5] Book:: MATLAB and Its Applications in Engineering, R K Bansal, A K Goel, M Sharma, Pearson Education India, 2009.

[6] $\mathrm{Z} \mathrm{Wu}$ and $\mathrm{Yu}$ Zhou, "Service Trustworthiness Evaluation Using Neural Network and Fuzzy Logic", Services Computing (SCC) 2016 IEEE International Conference on, pp. 563-570, 2016.

[7] G Acampora, A Castiglione and A Vitiello, "A fuzzy logic based reputation system for E-markets", Fuzzy Systems (FUZZ-IEEE) 2014 IEEE International Conference on, pp. 865-872, 2014.

[8] Z Li, H Lin, C Lu and Y Zhang, "Managing Data for Evaluating Trust in Unstructured Peer-to-Peer Networks", Advances in Grid and Pervasive Computing. GPC 2008. Lecture Notes in Computer Science, Vol. 5036, Springer, Berlin, Heidelberg.

[9] Book:: Rule Based Expert Systems: The Mycin Experiments of the Stanford Heuristic Programming Project, B G Buchanan, The Addison-Wesley series in artificial intelligence, 1st Edition.

[10] T Oliveira, M Alhinho, P Rita and G Dhillon, "Modelling and testing consumer trust dimensions in e-commerce", Computers in Human Behavior Vol. 71, pp. 153-164, 2017.

[11] J Mahmud, Y Borodin, M A Islam and F Ahmed, "Bridging the Web Accessibility", Electronic Notes in Theoretical Computer Science, Elsevier, 2009.

[12] http://en.wikipedia.org/wiki/Ethnography.

[13] S Trewin, B Cragun, C Swart, J Brezin and J Richards, "Accessibility challenges and tool features: an IBM Web developer perspective", International Cross Disciplinary Conference on Web Accessibility (W4A), ACM, 2010.

[14] Book:: Human-Computer Interaction, A Dix, J Finlay, G Abowd, and R Beale. Prentice Hall, 2004.

[15] M A Islam, F Ahmed, Y Borodin, J Mahmud and I V Ramakrishnan, "Improving Accessibility of Transaction-centric Web Objects", SIAM International Conference on Data Mining (SDM), 2010.

[16] http://www.usabilityinstitute.com/resources/stateoftheart.htm

[17] J Offutt, "Quality attributes of Web software applications", IEEE Software: Special Issue on Software Engineering of Internet Software, pp. 25-32, 2002.

[18] F Adrian, I Emilio and A Silvia, "Usability evaluation methods for the web: A systematic mapping study", Information and Software Technology, pp. 789-817, 2011.

[19] A Salim and B Abdelmajid" "An evaluation study of the navigation and search systems on two academic websites and Google", The International Information \& Library Review, pp. 50-61, 2010.

[20] H Hartson, T Andre and R Williges, "Criteria for evaluating usability evaluation methods", International journal of human-computer interaction, pp. 373-410, 2001.

[21] F Lia and Y Lib, "Usability evaluation of e-commerce on B2C websites in China", Elsevier, 2011. 